\title{
FACTORS OF THE SIZE OF GOVERNMENT IN DEVELOPED COUNTRIES
}

\author{
Boris Gramc*
}

\begin{abstract}
:
The purpose of the analysis presented in the paper is to identify various factors, including economic, social, political, demographic and cultural ones, that could shape the differences in the size of government across countries and to verify their effect with the use of econometric analysis. The analysis focuses on "budgetary" government, usually measured with some government spending ratio, as well as on "non-budgetary" government, measured with the index of the extent of regulation in the economy. The results of the analysis show that economic factors are more important in explaining the variation in the size of government consumption and in the size of non-budgetary government, whereas political, social and cultural factors are more important in explaining the variation in the size of transfers. Besides, the results also indicate, that there exists "trade-off" between budgetary and non-budgetary government.
\end{abstract}

Keywords: the size of the government, econometrics, politics, economic policy.

JEL Classification: H11, H60

\section{Introduction}

One of the major current issues in the social sciences is the expansion of government in recent times. Namely, absolute and relative size of government sectors grew rapidly in the majority of industrialised countries over the past century. ${ }^{1}$ It is worth noting that the literature on the determinants affecting the growth in size of government is quite comprehensive and numerous explanations have been developed (e.g., see Lane, 2000; Tanzi and Schuknecht, 2000; Bailey, 2002). The first attempts to account for the exceptional public sector growth in developed countries were the so-called demand side hypotheses. Demand theories suggested among other things that socio-economic development implies public resource allocation, that increasing affluence implies larger budgets, that the dominance of the left in society or government would mean budget expansion replacing market mechanisms, that collective ideologies would promote public sector expansion, that sudden social shocks necessitated budgetary shift-points towards much higher levels of public spending, that welfare spending by neighbourhood state implied a demand for welfare programmes at home, and that the increasing openness of

* University of Ljubljana, Faculty of Administration, Gosarjeva ulica 5, SI - 1000 Ljubljana (boris.gramc@fu.uni-lj.si)

1 For the industrialised countries, the share of government spending in GDP grew, on average, from about 12 per cent before World War I to about 45 per cent in the middle of 1990s (Tanzi, 1997). 
the developed economies of the world created a demand for budgetary stabilizing of the erratic fluctuations of markets (Wagner, 1883; Peacock and Wiseman, 1961; Wildavsky, 1964; Berry and Lowery, 1987; Alesina and Perrotti, 1995; Payne, 1991; Rowley and Tollison, 1994; Kraan, 1996; Kau and Rubin, 2002).

These demand hypotheses may be classified as either economic or political. They are supported by no generally empirical evidence from policy-making in various developed countries. Either they lack outright substantial empirical confirmation or they model the relationship between determinants and budgetary decision-making inadequately, as demand models tend to lack one crucial variable: the institutional context for policy-making (Persson, 2002).

The second stage in the debate about public sector growth was supply oriented. Here we find the hypothesis that public spending involves bureaucratic waste, that public sector growth is a function of bureau size maximization, that public sector productivity is negative, claiming more resources every year for the output, that budget-making rests upon fiscal illusions about the relation between cost and benefit and that an invisible tax structure and high tax elasticities promote big spending. To these hypotheses we can also add the "law" that the basic structure of the public sector implies budget-making which favours the supply of goods, services and money at the expense of genuine demand for these entities (Baumol, 1967; Downs, 1967; Niskanen, 1971; Tullock, 1980; Buchanan, 1980; Mueller, 2003).

The supply side approach basically concerns the logic of the interests that are to be found on the demand and supply side of the public household. It shares with Olson's "law" about distributional coalitions and distrust of the role of interest organizations in budgetary contexts (Olson, 1971). It agrees with Breton's "law" that public officials, whether bureaucrats or professionals, are motivated by a private interest function related to budget size, and it shares with Wicksell's "law" the idea that efficiency in budget-making presupposes that cost and benefit are closely interrelated somehow (Lane, 2000).

The increase in collective expenditures is only part of the story. In addition to the rapid growth in spending and taxing, there has also been a vast expansion in the laws and regulations governing economic affairs. Bad policies and regulations induce economic agents to go into the informal economy and they also discourage people from being innovative if they produce an environment that does not protect the property rights in innovations and does not provide hopes for a reasonable return (Derthick and Quirk, 1985). In addition to regulating the prices and standards of business the nation also attempts to protect health and safety through increasingly stringent social regulation. We will include all of these aspects.

However, growth in government spending and regulation was not fully symmetrical across countries, indicating that large cross-country differences in the size of government exist nowadays, even among developed countries. ${ }^{2}$ Consequently, the main

2 For instance, based on Economic Outlook (OECD, 2004) and Annual Report (EBRD, 2004) data, in South Korea total general government expenditures were approximately 20 per cent of GDP in 2003. That share was approximately 30 per cent in Ireland and something below 40 per cent of GDP in the United Kingdom. Slovenia, as an example of the developed transition economy, had government spending above 40 per cent of GDP. However, government appropriated even more than 50 per cent of GDP in countries like Denmark and Sweden. 
question that ought to be answered in the paper is, why such differences exist in the size of government and which factors shape those differences. In other words, the answer to the question concerning the reasons behind the fact why one country is economically more "free" than the other should be provided. Therefore, the aim of the analysis presented in the paper is to theoretically identify various economic, political, social, demographical and cultural factors influencing the variations in the size of government across countries and to empirically verify the effect of those factors on the size of government with the use of panel data analysis.

\section{Determinants of the Size of Government}

Let us firstly expose two important questions that relate to the size of government. First question refers to measuring the size of government. A variety of ways exist in the literature by which the size of government is measured. These measures are usually spending based, typically with total general government expenditures or general government consumption expenditures. ${ }^{3}$ Still, the main relative measure of the size of government is the government expenditures ratio (total government outlays as a percentage of gross domestic product) and should characterise the extent of government utilisation of domestic resources. Total government expenditures include spending on general government consumption, transfers and subsidies, net interest on outstanding debt, and capital goods. ${ }^{4}$

On the other side Posner (1971) stresses, fiscal instruments are only one of two instruments for executing public (government) policy, the other instrument being regulation. Moreover, Leonard (1986) argues that government budgets will understate the true size of the government sector by not recording the so-called "quiet side" of government activity ("non-budgetary" government). Consequently, it can be derived that the influence of government in an economy goes beyond its spending activities and tax collections. For example, regulation of economic activities or governmental ownership of enterprises are two examples of government intervention that can have little impact on the size of government budget, but they can have profound economic effects.

The second important question in modern political economy is the explanation of public sector expansion in the developed economies. As mentioned above, the literature on determinants of government growth is quite substantial. Theoretical ingenuity has not been lacking since a large number of different hypotheses have been suggested including some very bold conjectures. Nor has there been scarcity of empirical labour because vast amounts of data have been examined in detail for most of OECD countries, aggregating and disaggregating public finance information in a variety of ways. But results are very meagre.

3 The latter is used more frequently as it is usually available for a wider range of countries. However, this measure only encompasses certain aspect of government activities and not all of them.

4 Some cross-country studies use central government expenditures as a share of GDP to measure the size of government. However, as stated by Gwartney et al. (1998), those figures can often be highly misleading, because the central government figures understate the size of government for countries where substantial expenditures are undertaken at lower levels of government. 
Maybe the gulf between scientific endeavour and findings is so striking that it is time to look more closely at the methodological assumptions underlying the public policy, public finance and public choice theories to the interpretation of the growth of government. If a problem is intractable, then perhaps it should be framed differently. The explanatory approaches to the problem of public sector expansion may be cross-sectional or longitudinal, institutional or non-institutional and demand or supply oriented. Our analysis includes both cross-sectional and longitudinal approaches through panel data analysis, it captures institutional variables and combines demand and supply theories. In the following we firstly explain the different factors influence on budgetary size of government.

Alesina and Warcziarg (1998) argue that the size of government correlates negatively with country size and positively with trade openness, contrary to what most economists would expect. They have shown that smaller countries have a larger share of government consumption in GDP, and are also more open to trade. Moreover, they argue that these empirical observations are consistent with recent theoretical models explaining country formation and break up. Namely, larger countries can "afford" to be closed, while small countries face stronger incentives to remain open. Conversely, as trade liberalizes, regional and cultural minorities can "afford" to split because political borders do not identify the size of market. ${ }^{5}$ Similarly, Rodrik (1998) finds a strong positive association between openness and government size. He shows that higher levels of government consumption would be associated with reduced volatility in income flows. These findings also suggest that the international economic liberalism obviously gives government a central role and Ruggie (1982) calls this "the compromise of embedded liberalism".

Moreover, Eichner and Wagener (2002) argue that the optimal size of welfare state is larger the higher are the risks that it cannot insure (the so-called background risks). ${ }^{6}$

According to Wagner's and Wilensky's hypothesis, more developed countries should have larger government. Besides, it can be argued that larger urbanization rate of a country should positively affect government spending, since urbanization is likely to facilitate increasing taxation and to create more demands for government spending. Similarly, the share of dependent population positively affects demand for social services and consequently government spending (Holsey and Borcherding, 1997). In addition, governments should spend more in societies with relatively unequal income distribution because the median voter is poorer than the mean voter (McNutt, 1996). The benefits to a median voter of redistributive spending outweigh the costs of increased taxation to finance spending (Persson and Tabellini, 1999).

5 Economic literature on country formation and break up is another interesting field within public sector economics. In more recent text, Alesina, Spolaore and Wacziarg (2003) show that the benefits of size decline relative to the cost of heterogeneity, meaning that the optimal size of a country declines with trade openness. This means that smaller countries can enjoy the benefits of cultural homogeneity without suffering the costs associated with small markets.

6 This view highly challenges classical liberal expectations that the combination of globalization of the economies with the onset of new technologies will transform modern governments back into a night-watchman state. 
It is also crucial to include political institutions and regimes in the analysis. Let us define democracy as the extent to which voters decide over the political survival of the incumbent government (Pluemper and Martin, 2003). Since the general population becomes more important with growing levels of democracy while the importance of the elite declines we should expect a growing share of public investment in collective goods and decline in rental transfers. Pluemper and Martin (2003) show that there exists a non-linear, u-shaped relationship between levels of democracy and government consumption (see also Barro, 1998). With levels of democracy increasing, not only the type of government spending changes, but also the government's share in the economy.

For instance, Husted and Kenny (1997) show that government spending on the state level in the US increased after poll taxes had been abandoned. Because higher costs of voting disproportionally disfranchise people at the lower end of the income distribution, their inclusion in the voting franchise lowers the median income. Thus, the demand for redistribution of income rises. On a similar vein, Abrams and Settle (1999) show that in Switzerland, the extension of franchise to women in 1971 not only increased the size of Swiss government, but also changed the composition of the government's budget: their estimate point to a disproportionate increase in social welfare spending as an effect of introducing universal suffrage at the federal level. ${ }^{7}$ The level of democracy thus matters.

Finally, social diversification also seems important. This factor should have two counteracting influences. On the one hand, Annett (2000) has revealed that higher social diversification (as measured along ethno-linguistic and religious dimensions) leads exogenously to greater political instability, and governments use government consumption as a buffer against political instability. The effect of social diversification on government consumption is positive, but indirect, via the political instability channel. In a somewhat different fashion, Alesina et al. (2001) argue that the differences in level of redistribution between the United States and the European countries appear to be the result of racial heterogeneity, since racial aversion in the United States obviously makes redistribution to the poor, who are disproportionately black, unappealing to many voters. ${ }^{8}$

The theory and practice show that the size of government does not mean only budgetary but also non-budgetary government. The term non-budgetary government indicates that government activities are not "visible", since they are not directly perceivable in the amount of government spending. The non-budgetary government usually appears in the form of various regulatory demands set by government in order to oversee individual behaviour. Formally, OECD definition states that regulation refers to the diverse set of instruments by which governments set requirements on enterprises and citizens (Report on Regulatory Reform, OECD, 1997). There is no generally accepted economic theory about the determinants of macro extent of government regulation. One of rare attempts to identify determinants of regulation was undertaken

7 It hardly comes as a surprise that even US senators believe that good politics means new spending programmes, particularly for constituents who would be likely to contribute to one's re-election (Payne, 1991).

8 Accordingly, authors stress that the largest difference in the composition of government spending between the United States and Europe is in the area of transfers to households (including social security), and subsidies, which are the main tools for income redistribution. 
by Pryor (2002) who identifies several plausible causal factors of determinants of regulation, although his approach was in its essence more expeditious and inductive. Although Pryor empirically examined all those determinants on the sample of 18 OECD countries, statistical confirmation received only two factors, namely the size of the economy and income inequality. His results suggest that the degree of economic laissez-faire is inversely related to economic size and directly related to income inequality. He argues that this direct relationship is particularly important in political economy because it suggests that power relations between income groups are crucial in determining the extent of the regulatory regime.

Although the majority of economists see government ownership of enterprises and the extent of regulation of the economy as substitutes, Pryor argues that governmental regulation and ownership are complements, since both of them spring from the same urge to control private economic activity.

\section{Empirical Analysis}

\subsection{Data and Methodology}

The aim of the analysis is to identify factors influencing the variations in the size of government across countries and the relationship between budgetary and non-budgetary government. Therefore, panel data modelling is used in order to focus upon international and time comparison in variations in the size of government. Panel data econometric modelling is based on a sample of 35 developed democratic countries for which data on relevant explanatory and dependent variables for period 1980-2002 could be obtained. ${ }^{9}$ The theory about size and scope of government implies that certain common factors exist which might affect the differences in the size of budgetary and non-budgetary government across countries, although the direction of influence may differ.

The dependent variables in the analysis are the share of general government consumption spending in GDP $(C O N)$, the share of general government transfers and subsidies in GDP $(T R F)$ and the share of total general government expenditures in GDP $(E X P)$ as measures of the size of budgetary government. ${ }^{10}$ Besides, the extent of total regulation of the economy (REGUL) is used as measure of the size of non-budgetary government. Based od Gwartney and Lawson (2002) the REGUL variable measures the extent of total regulation of the economy where value 0 reflects minimalist regulatory state and value 10 highly regulated economy.

In addition, following explanatory variables are used in the regression analysis.

Wagner's law states that government spending both absolutely and relatively expands as economies develop. Therefore it is to be expected that the level of GDP per capita would positively affect the size of budgetary government, but the effect on the

9 The sample consists of 30 OECD member countries plus Estonia, Latvia, Lithuania, Poland and Slovenia.

10 The purpose of using three different measures of the size of budgetary government is in capturing possible different directions of influence of various explanatory variables on two main components of government spending, consumption and transfer spending. 
size of non-budgetary government should not be exposed with reasonable certainty due to the countervailing affect of the economic development on the extent of regulation. Also, the effect of the country size on the extent of regulation could not be predicted because of two countervailing affects.

Theory and every day life recognize the importance and side effects of population ageing. This involves increased demand for government spending on health care, social security, etc., so it is to be expected that dependency variable (citizens over 65 to total population) should positively affect government size, but there is no rationale to predict any affect on the size of non-budgetary government. The latter could be expected also for the urbanization rate and the rate of income inequality (Gini coefficient). On the other hand, the share of population living in urban areas should positively affect the size of government spending, since urbanization is likely to facilitate increasing taxation and to create more demands for government spending. Moreover, governments should spend more in societies with relatively unequal income distribution because the median voter is poorer than the mean voter. Therefore, it is expected that high levels of Gini coefficient would positively affect the differences in the size of budgetary government across countries.

Next, it is expected that the level of democracy should affect the size of budgetary government but the effect should be non-linear. We use the Polity98 dataset which has become the dominating measure of democracy over the last decade (Brunetti, 1997). Its main focus is on institutional aspects of political participation and employs subjective evaluations. We use standardized variable DEMOCRACY that stretches from 0 for pure autocracies to 10 for pure democracies. The Polity variables do not correlate with other variables included in regressions. ${ }^{11}$

Finally, we expect that social diversification variable should have two countervailing effects. On the one hand, it should negatively affect government spending through political instability channel. Namely, in more heterogeneous societies government spending to different groups within society should serve as a means of increasing the political stability of a country, meaning that spending through this "channel" should be minimized in more homogeneous countries. On the other hand, it should positively affect government spending, since in more homogeneous societies voters are likely to approve increased spending to certain social groups, because it is larger probability that they do not belong to certain ethno-religious minority. This effect is based on presumption that it is in human nature to prefer the people of the same kind (Pevcin, 2004).

Variables used in regression and their sources are presented in Table 1.

11 Gurr and Jaggers, the principal investigators of the Polity project, compute a democracy and an autocracy score, both ranging from 0 to 10 . To obtain the level of democracy, they recommend to subtract the countries' autocracy from its democracy score (Jaggers and Gurr, 1995). The resulting variable ranges from -10 to +10 . Since this does not permit a control for non-linearity, we standardize the variable so that it stretches from 0 to 10 . 
Table 1

Variable Description and Data Sources

\begin{tabular}{|c|c|c|}
\hline Variable & Description & Data source \\
\hline$C O N$ & $\begin{array}{l}\text { General government consumption } \\
\text { expenditure }(\% \text { GDP })\end{array}$ & IMF World Development Indicators \\
\hline$E X P$ & $\begin{array}{l}\text { Total general government } \\
\text { expenditure }(\% \text { GDP })\end{array}$ & $\begin{array}{l}\text { OECD Economic Outlook; EBRD } \\
\text { Annual Report (2004); IMF World } \\
\text { Development Indicators }\end{array}$ \\
\hline$G D P$ & $\begin{array}{l}\text { Real gross domestic product per } \\
\text { capita (in USD) }\end{array}$ & World Development Indicators \\
\hline$R E G U L$ & $\begin{array}{l}\text { Extent of total regulation of the } \\
\text { economy; values between } 0(\mathrm{~min}) \\
\text { and } 10(\max )\end{array}$ & $\begin{array}{l}\text { Based on Gwartney and Lawson } \\
\text { (2002) }\end{array}$ \\
\hline OPEN & $\begin{array}{l}\text { Trade openness (sum of the share of } \\
\text { imports and exports in \% of GDP) }\end{array}$ & World Development Indicators \\
\hline DEPRATIO & $\begin{array}{l}\text { Share of population older than } 65 \\
\text { years in total population }(\%)\end{array}$ & $\begin{array}{l}\text { U.S. Census, International Database, } \\
\text { OECD Social Statistics, Eurostat }\end{array}$ \\
\hline GINI & $\begin{array}{l}\text { Income distribution in economy, } \\
\text { measured with Gini coefficient } \\
\text { multiplied by } 100\end{array}$ & $\begin{array}{l}\text { World Development Indicators } \\
\text { (2005) }\end{array}$ \\
\hline$U R B A N$ & $\begin{array}{l}\text { Urbanisation rate of a country (share } \\
\text { of urban population in } \% \text { of total } \\
\text { population) }\end{array}$ & World Development Indicators \\
\hline DEMOCRACY & $\begin{array}{l}\text { Level of democracy; } 0 \text { - pure } \\
\text { autocracy, } 10 \text { - pure democracy }\end{array}$ & Polity IV dataset. \\
\hline SOCDIVERS & $\begin{array}{l}\text { Social diversification (share of } \\
\text { largest ethno-religious group in } \% \text { of } \\
\text { total population) }\end{array}$ & Encarta Encyclopedia \\
\hline
\end{tabular}

We use three econometric data analysis techniques, pooled OLS, fixed effects and random effects model. A pooled regression simply assumes that all parameters are the same for each country. The main problem is that this specification ignores factors that may be specific to each country. In addition, time-series effects are likely to be drowned out by cross-sectional variation.

The most common panel estimator is the one-way fixed effects estimator (FE), which allows the intercept to differ across countries. Taking deviations in this way means that only within-country variation is considered, while the between-country cross-sectional relation is factored out. The random effects estimator (RE) treats the country-specific effects as random, coming from some probability distribution, and tends to give results in between the simple pooled estimator and the fixed effects model. However, it has the disadvantage that it is rendered inconsistent by correlation between the fixed effects and the regressors, which makes it particularly unsuitable in this case. The fixed effects model does not share this problem (Baltagi, 2001). 


\subsection{Results and Discussion}

The results of empirical analysis of factors causing differences in the size (and structure) of government spending and scope of regulation are presented in Tables 2-3. ${ }^{12}$

\section{Table 2}

Factors Affecting Government Consumption Spending in Developed Countries ( $t$-statistics are in parenthesis)

\begin{tabular}{|l|c|c|c|}
\hline Dependent variable $\boldsymbol{C O N}$ & Pooled OLS & Fixed Effects & Random Effects \\
\hline DEPRATIO & $\begin{array}{c}0.5549 \\
\left(5.89^{* * *}\right)\end{array}$ & $\begin{array}{c}0.5065 \\
\left(4.13^{* * *}\right)\end{array}$ & $\begin{array}{c}0.5213 \\
\left(4.52^{* * *}\right)\end{array}$ \\
\hline \multirow{2}{*}{ URBAN } & $\begin{array}{c}0.1088 \\
\left(3.07^{* * *}\right)\end{array}$ & $\begin{array}{c}0.1102 \\
\left(3.76^{* * *}\right)\end{array}$ & $\begin{array}{c}0.1134 \\
\left(3.88^{* * *}\right)\end{array}$ \\
\hline \multirow{2}{*}{ GINI } & -0.3348 & -0.3350 & -0.3339 \\
& $\left(-2.75^{* *}\right)$ & $\left(-2.81^{* *}\right)$ & $\left(-2.54^{* *}\right)$ \\
\hline$R^{2}$ adj. & 0.632 & 0.746 & 0.442 \\
\hline F-stat. & 1145.22 & 5764.23 & 3987.43 \\
\hline Poolability test & \multicolumn{3}{|c|}{$\mathrm{F}=465.87(\mathrm{p}=0.000)$} \\
\hline LM-test & $\mathrm{LM}=176.75(\mathrm{p}=0.000)$ \\
\hline Hausmann test & $\mathrm{m}=9.76(\mathrm{p}=0.015)$ \\
\hline
\end{tabular}

* ${ }^{* *}$ and ${ }^{* * *}$ represent statistical significance at 10,5 and 1 percent respectively.

The results in Table 2 indicate that share of population above 65 and urbanization rate of the country positively affect government consumption expenditure. Not surprisingly, the results also reveal that the size of Gini coefficient negatively affects government consumption in developed countries. In countries with more unequal income distribution governments spend less on consumption and - as we expect-more on social transfers. Poolability test shows that we reject the null hypothesis of the same constant for all groups and testing the difference between pooled OLS and random effects models (LM-test) shows that the later is in favour. Using Hausmann test we also reject the null that random effects model is proper. Therefore, fixed effects model seems to give the most reliable results.

12 In all tables, only statistically significant variables (at $10 \%$ margin) are presented, values of t-statistics being in parentheses. 
Table 3

Factors Affecting Government Transfer Spending in Developed Countries (t-statistics are in parenthesis)

\begin{tabular}{|c|c|c|c|}
\hline Dependent variable $T R F$ & Pooled OLS & Fixed Effects & Random Effects \\
\hline OPEN & $\begin{array}{l}0.0551 \\
\left(2.39^{* *}\right) \\
\end{array}$ & $\begin{array}{l}0.0502 \\
\left(2.09^{*}\right) \\
\end{array}$ & $\begin{array}{l}0.0502 \\
\left(2.15^{* *}\right) \\
\end{array}$ \\
\hline DEMOCRACY & $\begin{array}{l}0.1413 \\
\left(2.14^{* *}\right) \\
\end{array}$ & $\begin{array}{r}0.1475 \\
\left(2.43^{* *}\right) \\
\end{array}$ & $\begin{array}{c}0.1462 \\
\left(2.22^{* *}\right) \\
\end{array}$ \\
\hline$R E G U L$ & $\begin{array}{c}1.3842 \\
\left(3.18^{* * *}\right) \\
\end{array}$ & $\begin{array}{r}1.3900 \\
\left(3.42^{* * *}\right) \\
\end{array}$ & $\begin{array}{c}1.3943 \\
\left(3.45^{* * *}\right) \\
\end{array}$ \\
\hline GINI & $\begin{array}{l}0.7277 \\
\left(2.14^{* *}\right) \\
\end{array}$ & $\begin{array}{l}0.7220 \\
\left(1.96^{*}\right) \\
\end{array}$ & $\begin{array}{c}0.7302 \\
\left(3.02^{* * *}\right)\end{array}$ \\
\hline$R^{2} a d j$ & 0.555 & 0.602 & 0.589 \\
\hline$F$-stat. & 976.54 & 3866.03 & 3863.92 \\
\hline Poolability test & \multicolumn{3}{|c|}{$\mathrm{F}=133.54(\mathrm{p}=0.000)$} \\
\hline LM-test & \multicolumn{3}{|c|}{$\mathrm{LM}=487.88(\mathrm{p}=0.000)$} \\
\hline Hausmann test & \multicolumn{3}{|c|}{$\mathrm{m}=10.47(\mathrm{p}=0.073)$} \\
\hline
\end{tabular}

* ${ }^{* *}$ and ${ }^{* * *}$ represent statistical significance at 10,5 and 1 percent respectively.

Next, results in Table 3 indicate that more open countries should have larger transfer spending, which is in line with Rodrik's findings that governments provide social insurance against the risk of terms of trade shocks that open economies face. It is evident that social insurance can easily be provided with increased transfers and subsidies. According to theoretical predictions, transfer spending is positively associated with Gini coefficient. Higher level of democracy linked with higher transfer payments though the absolute effect is relatively small; this is accordance with predictions that democratic political parties compete with each other using transfers and subsidies to various target groups. At this point we find linear relationship between transfer spending and democracy. It is also reasonable that higher level of regulation means higher government's transfer spending because many regulated industries are supported with considerable subsidies. Surprisingly, the share of population above 65 seems to explain the variation in government consumption expenditures but not in government transfers and subsidies in this group of developed countries.

Again, poolability test, Hausmann test and LM-test show that fixed effects model is the right thing to do.

When we run regression with total general government spending as dependent variable we find out that none of the explanatory variables has significant explanatory effect at $10 \%$ level. This means that government spending can be modelled easier if its separate components are analysed, suggesting that different factors obviously affect consumption and transfer spending.

The results in Table 4 indicate that pooled OLS is better choice in this case and that only two variables are statistically significant explainers of the variations in the size of total government spending. It is shown that the extent of regulation decreases with the level of economic development and with income inequality in society. We expect that above all government uses budgetary instruments to ease income inequality. The result 
could be interpreted as that higher Gini coefficient reduces regulation but - as shown in Table 3 - enlarges transfer payments. Intuitively, it should be expected that budgetary and non-budgetary government should act as substitutes; ${ }^{13}$ our data and analysis confirm this intuition. Possible explanation is that the extension of regulation of the economy should act as a direct substitute to the fiscal instruments of the government. The reason could be in the fact that the existence of small government (in terms of fiscal instruments) indicates that private sector has a very large role in the economy and government oversees its activity through the regulation. In this context, possible "transmission mechanism of government activities" could be developed, as the association between budgetary and non-budgetary government could possibly also be indirect. Namely, as globalist or even mercantilists view points, larger openness of the country hampers the ability of government to regulate the economy. Reduced regulation boost gross domestic product growth and according to Wagner's hypothesis this very likely increases government spending (Pevcin, 2004). The univariate regression between $\log (G D P)$ and regulation was made. It was shown that coefficient on REGUL was not significantly different from zero. Also, results in Table 2 and Table 4 show that the level GDP per capita and country's openness do not have significant influence on government consumption. Therefore the "governmental transmission mechanism" hypothesis cannot be supported. There are rather political reasons why governments in some cases prefer spending but in others regulation.

\section{Conclusions}

In the paper, differences in the size of government sector are analysed using panel data. In this context, the main question that ought to be answered is why differences in the size exist and which economic, political, cultural, demographic and social factors shape those differences, altogether aimed at developing theoretical and empirical foundations of modern theory of government. The results obtained by the empirical analysis of the determinants that cause the differences in the size of government across countries revealed that the form of government activities (budgetary versus non-budgetary) and composition of government spending matters in explaining differences, as economic factors are more important in explaining the variation in the size of consumption spending and in the size of non-budgetary government, whereas political, social and cultural factors are more important in explaining the variation in the size of transfer spending. The results obtained also indicate that the size of budgetary government and the size of non-budgetary government move in the opposite direction.

13 The possible reason could be the simple mathematical fact; if they could be both transformed into budgetary forms, their sum could not exceed the size that is preferred or demanded by voters or taxpayers - in the worst case the size of government could not exceed the total economy output. This implies that more of one form of government is associated with the smaller extent of other form (Pevcin, 2004). 


\section{References}

Abrams, B.A., Settle, R.F. (1999), "Women's Suffrage and the Growth of the Welfare State." Public Choice, 100 (3-4), pp. 289-300.

Alesina, A., Perrotti, R. (1995), "The Political Economy of Budget Deficits." IMF Staff Papers, 24, pp. $1-32$.

Alesina, A., Glaeser, E., Sacerdote, B. (2001), "Why Doesn't the US Have a European-Style Welfare System?" Cambridge : NBER.

Alesina, A., Wacziarg, R. (1998), "Openness, Country Size and the Government." Journal of Public Economics, 69, pp. 305-321.

Alesina, A., Spolaore, E., Wacziarg, R. (2003), Trade, Growth and the Size of Countries. Cambridge : Harvard University.

Annett, A. (2000), Social Fractionalization, Political Instability, and the Size of Government. Washington : IMF.

Bailey, S.J. (2002), Public Sector Economics. Basingstoke : Palgrave.

Baltagi, B.H. (2001), Econometric Analysis of Panel Data. Chichester : Wiley.

Barro, R.J. (1998), Determinants of Economic Growth: A Cross-Country Empirical Study. Cambridge : MIT Press.

Baumol, W.J. (1965), Welfare Economics and the Theory of the State. London : Bell.

Berry, W.D., Lowery, D. (1987), "Explaining the Size of the Public Sector: Responsive and Excessive Government Interpretations." The Journal of Politics, 49 (2), pp. 400-420.

Brunetti, A. (1997), "Political Variables in Cross-Country Growth Analysis." Journal of Economic Surveys, 11 (1), pp. 163-190.

Buchanan, J.M. (1980), "Rent Seeking and Profit Seeking," in Buchanan, J.M., Tollison, R.D., Tullock, G., eds., Toward a Theory of the Rent-Seeking Society. Texas: Texas A\&M University Press, College Station, pp. 3-15.

Derthick, M., Quirk, P. (1985), The Politics of Regulation. Washington, DC : Brookings.

Downs A. (1967), Inside Bureaucracy. Boston : Little Brown.

Eichner, T., Wagener, A. (2002), Increases in Risk and the Welfare State. Munich : CESIFO.

Gwartney, J., Holcombe, R., Lawson, R. (1998), "The Scope of Government and the Wealth of Nations." Cato Journal, 18 (2), pp. 163-190.

Holsey, C., Borcherding, T. (1997), "Why Does Government's Share of National Income Grow," in Mueller, D. (ed.): Perspectives on Public Choice. New York : CUP, pp. 569-590.

Husted, T.A., Kenny, L.W. (1997), "The Effect of the Expansion of the Voting Franchise on the Size of Government." Journal of Political Economy, 105, pp. 54-82.

Jaggers, K., Gurr, T. R. (1995), "Tracking Democracy's Third Wave with Polity III Data." Journal of Peace Research, 32 (4), pp. 469-482.

Kraan, D.J. (1996), Budgetary Decisions. A Public Choice Approach. Cambridge : Cambridge University Press.

Kau, J.B., Rubin, P.H. (2002), "The Growth of Government: Sources and Limits." Public Choice, 113 (3-4), pp. 389-402.

Lane, J. (1995), The Public Sector. London: SAGE Publications.

Leonard, H.B. (1986), Checks Unbalanced: The Quiet Side of Public Spending. New York : Basic Books.

McNutt, P.A. (1996), The Economics of Public Choice. Cheltenham : Edward Elgar, Brookfield.

Mueller, D.C. (2003), Public Choice III. Cambridge : Cambridge University Press.

Niskanen, W.A. (1971), Bureaucracy and Representative Government. Chicago : Aldine.

Olson, M. (1971), The Logic of Collective Action. Cambridge : Harvard University Press.

Payne, J.L. (1991), "Elections and Government Spending." Public Choice, 70 (1-2), pp. 71-82.

Peacock, A.T., Wiseman, J. (1961), The Growth of Public Expenditures in the United Kingdom. Princeton : Princeton University Press.

Persson, T. (2002), "Do Political Institutions Shape Economic Policy?" Econometrica, 70 (3), pp. 883-895.

Persson, T., Tabellini, G. (1999), Political Economics and Public Finance. Cambridge : NBER.

Pevcin, P. (2004), "Determinants of the Size of Government and Their Implications for Public Sector Reform in Slovenia." Doctoral Dissertation. Faculty of Economics, Ljubljana. 
Pluemper, T., Martin, C.W. (2003), "Democracy, Government Spending, and Economic Growth: A Political-Economic Explanation of the Barro-effect." Public Choice, 117 (1-2), pp. 27-50.

Posner, R. (1971), "Regulation as Taxation." The Bell Journal, 2 (1), pp. 22-50.

Pryor, F. (2002), "Quantitative Notes on the Extent of Governmental Regulations in Various OECD Nations." International Journal of Industrial Organization, 20 (5), pp. 693-714.

Rodrik, D. (1998), "Why Do More Open Economies Have Bigger Governments?" Journal of Political Economy, 106 (5), pp. 997-1032.

Rowley, C.K., Tollison, R.D. (1994), "Peacock and Wiseman on the Growth of Public Expenditure." Public Choice, 78 (2), pp. 125-128.

Ruggie, J. (1982), "International Regimes, Transactions, and Change." International Organization, 36 (2), pp. 379-415.

Tanzi, V., Schuknecht, L. (2000), Public Spending in the 20th Century. Cambridge : CUP.

Tullock, G. (1980), "Efficient Rent Seeking," in Buchanan, J.M., Tollison, R.D., Tullock ,G., eds., Towards a Theory of Rent Seeking Society. Texas : Texas A\&M University Press, College Station, pp. 14-34.

Wagner, A. (1883), Finanzwissenschaft. Leipzig.

Wildavsky, A. (1964), The Politics of the Budgetary Process. Boston : Little Brown. 